Vol. 1 No. 2 2018, Hal. 85-99

\title{
GENDER AND DEVELOPMENT (GAD): KETERPILIHAN PEREMPUAN DALAM PILKADA SERENTAK 2015, 2017 DAN 2018 DI PROVINSI JAWA TIMUR
}

\author{
Susi Dian Rahayu \\ Chairunnisa \\ Peneliti Uskaham \\ dan Sekretaris DPP KPPI \\ susidianrahayu@gmail.com, icha.nisamumtazah81@gmail.com
}

\begin{abstract}
The changes of the local government management system after the New Order regime from centralistic to decentralized provide significant changes to the region in Indonesia. Since that time, the region can determine its own affairs and needs, including the regional head. Direct regional head election (local election) is a product of decentralization. Through direct elections, the people have the right to determine their regional heads. In addition, direct elections also opened up opportunities for female candidates to compete in the elections, not a few of them won the contest. In the aftermath of the 2018 Local election, East Java Province has ten female regional heads spread in 38 regency/city, and is the only Province in Indonesia which is currently headed by a female governor. This paper analyzes the electability of women in the localelections in 2015, 2017 and 2018 in East Java as an implementation of the Gender and Development (GAD) concept. In addition, the analysis used in assessing women's electability in the local election in East Java Province uses four indicators, namely the basis of electability, the pattern of recruitment, regeneration of political party and also bonding with the community (grassroots).
\end{abstract}

Keywords: local election, gender and development, women's electability 


\begin{abstract}
Abstrak
Perubahan sistem pengelolaan pemerintah daerah pasca rezim Orde Baru dari sentralistik menjadi desentralistik memberikan perubahan yang signifikan bagi daerah. Hal tersebut dikarenakan sejak saat itu, daerah dapat menentukan sendiri urusan dan kebutuhannya, termasuk kepala daerahnya. Pemilihan kepala daerah secara langsung merupakan produk dari adanya desentralisasi. Melalui Pilkada langsung, rakyat berhak menentukan kepala daerahnya. Selain itu, Pilkada langsung juga membuka kesempatan kepada para calon perempuan untuk bersaing dalam Pilkada, tidak sedikit dari mereka yang memenangkan kontestasi tersebut. Pasca pelaksanaan Pilkada Serentak 2018, Provinsi Jawa Timur memiliki sepuluh kepala daerah perempuan yang tersebar di 38 Kabupaten/Kota, dan merupakan satu-satunya Provinsi di Indonesia yang saat ini dipimpin oleh gubernur perempuan. Paper ini menganalisis mengenai keterpilihan perempuan dalam pilkada serentak tahun 2015, 2017, dan 2018 di Jawa Timur sebagai implementasi dari konsep Gender and Development (GAD). Selain itu, analisis yang digunakan dalam mengkaji keterpilihan perempuan dalam Pilkada Serentak di Provinsi Jawa Timur menggunakan empat indikator, yakni Basis keterpilihan, Pola rekruitmen, Kaderisasi dan Ikatan dengan masyarakat (grassroot).
\end{abstract}

Kata Kunci: Pilkada Serentak, Gender and Development, Keterpilihan Perempuan

\section{Pendahuluan}

Jatuhnya rezim Orde Baru yang ditandai dengan mundurnya Presiden Soeharto pada tahun 1998 Ialu merupakan fase awal dari demokratisasi di Indonesia. Keberhasilan mahasiswa dan masyarakat sipil menumbangkan rezim Orde Baru merupakan momentum yang sangat fenomenal, selain menjadikan kekuatan militer yang kala itu sebagai kekuatan dominan ikut tumbang, reformasi 1998 juga dianggap sebagai pembuka keran kebebasan dari masyarakat Indonesia. Samuel Huntington dalam bukunya yang berjudul Gelombang Demokratisasi Ketiga menyebut fenomena atau gelombang demokratisasi merupakan perubahan atau pergantian berbagai rezim yang sebelumnya bersifat non demokratis menjadi demokratis. (Huntington, 1991, 13).

Merujuk pada definisi demokratisasinya Huntington, maka dapat dipahami bahwa proses demokratisasi di Indonesia terjadi pada tahun 1998 yang ditandai dengan tumbangnya rezim Orde Baru. Demokratisasi terbentuk untuk memberikan jalan bagi terbentuknya sistem tatanan yang sebelumnya nondemokratis menjadi demokratis. Salah satu agenda penting dari proses demokratisasi di Indonesia adalah adanya penerapan kebijakan desentralisasi. Penerapan desentralisasi di Indonesia berdasarkan UU No 22 tahun 1999 tentang Pemerintahan Daerah. Konsep desentralisasi yang diterapkan 
di Indonesia yaitu mengalihkan sebagian besar kewenangan pelayanan publik dari tingkat pusat ke pemerintah daerah. Sebelumnya, pada era Orde Baru, Indonesia menerapkan sistem sentralisasi dalam pemerintahannya. Segala sesuatu urusan daerah ditentukan oleh pusat, termasuk kepala daerah.

Penerapan desentralisasi atau sistem otonomi daerah kemudian terus mengalami perkembangan secara signifikan dengan disahkannya UU No 32 tahun 2004 tentang Pemerintah Daerah. Undang-undang tersebut secara implisit mengatur mengenai tugas dan wewenang Pemerintah Daerah, dan salah satu hal terpenting dari undang-undang tersebut adalah diterapkannya sistem pemilihan kepala daerah secara langsung di Indonesia (Pilkada langsung).

Indonesia pertama kali menggelar Pilkada langsung secara serentak pada Juni 2005 dengan memilih 7 (tujuh) Gubernur dan 155 Bupati/Walikota di seluruh Indonesia. Sejak saat itu, masyarakat di daerah berkesempatan untuk menentukan sendiri kepala daerahnya, hal tersebut disinyalir sebagai wujud representasi atas kedaulatan rakyat. Pelaksanaan Pilkada langsung merupakan bentuk pengukuhan terhadap otonomi rakyat di daerah dalam menentukan kepala pemerintahannya. Melalui Pilkada lagsung, rakyat dapat turut serta dalam penentuan pergantian penguasa. Adanya mekanisme Pilkada langsung ini disinyalir sebagai salah satu keran pembuka bagi partisipasi perempuan dalam Pilkada, salah satunya mengenai pencalonan dan keterpilihan perempuan dalam Pilkada.

Lahirnya Undang-undang No 32 tahun 2004 yang didahului dengan Undangundang No 22 tahun 1999 merupakan tonggak sejarah penting bagi Indonesia. Kedua Undang-undang tersebut telah mengubah sistem pemerintahan daerah yang sebelumnya sentralistis menjadi desentralisasi. Bahkan, pemilihan kepala daerah secara langsung berasal dari Undang-undang tersebut. Sebelumnya, selama kurang lebih 25 tahun, Indonesia menerapkan UU No 5 tahun 1974 sebagai dasar hukum pelaksanaan pemerintahan daerah. Selama itu pula, kepala daerah ditentukan oleh pusat. Kemudian, pasca reformasi lahir UU No 22 tahun 1999, yang merupakan tonggak awal reformasi. Undang-undang tersebut mengatur kepala daerah dipilih oleh DPRD, tanpa harus melalui persetujuan dari pusat, melalui Undang-undang ini muncul beberapa kepala daerah perempuan yang dipilih oleh DPRD, yakni Rustriningsih sebagai Bupati Kebumen (2000-2005), Haeny Relawati Bupati Tuban (20012006), Rina Iriani Bupati Karang Anyar (2003-2008) dan Tuti Hayati Anwar Bupati Majalengka (2003-2008). Kemudian, lahir Undang-undang No 32 tahun 2004 yang mengatur Pilkada secara langsung. Mekanisme Pilkada langsung telah membuka peluang partisipasi politik yang lebih besar pada berbagai elemen masyarakat, termasuk kaum perempuan untuk ikut mewarnai dan menentukan arah demokrasi lokal. Sejak dimulainya Pilkada langsung di berbagai wilayah Indonesia sejak tahun 2005, jumlah perempuan yang menjadi kandidat dan atau terpilih sebagai kepala daerah meningkat cukup signifikan. Pada Pilkada langsung selama dua periode (20052010) dan (2010-2014), terdapat 26 perempuan terpilih sebagai kepala daerah (18 di Pulau Jawa--Jawa Tengah, Jawa Timur, Jawa Barat, dan 8 perempuan di 
Iuar Pulau Jawa). Sementara itu, pada Pilkada langsung serentak tanggal 9 Desember 2015, tepilih 47 perempuan yang menjadi kepala daerah dan wakil kepala daerah, (Komariah, 2016 : 52) dan pada Pilkada serentak tahun 2017 terpilih 13 perempuan kepala daerah.

Jika berbicara mengenai Pilkada langsung, tentu tidak dapat disamakan dengan pemilu legislatif, karena dalam Pilkada langsung tidak memberikan affirmative action terhadap perempuan. Artinya, baik perempuan maupun laki-laki dihadapkan dalam persaingan bebas dalam memperebutkan posisi kepala daerah. Hal tersebut, tentu menjadi peluang sekaligus tantangan tersendiri bagi perempuan. Di satu sisi, budaya patriarki yang berkembang dalam masyarakat merupakan penghambat bagi perempuan untuk dapat maju dalam Pilkada. Selain itu, hambatan struktural lainnya yakni adanya persaingan yang tidak seimbang antara laki-laki dan perempuan serta minimnya akses yang diberikan oleh Partai Politik untuk pencalonan perempuan dalam Pilkada. Namun, seiring terbukanya persaingan bebas antara laki-laki dan perempuan dalam konteks Pilkada langsung juga diiringi dengan adanya berbagai kemenangan calon kepala daerah perempuan di berbagai wilayah, seperti di daerah Jawa Timur yang hingga saat ini memiliki sepuluh kepala daerah perempuan. Berdasarkan latar belakang permasalahan tersebut, paper ini hendak menganalisis mengenai keterpilihan perempuan dalam Pilkada Serentak tahun 2015, 2017 dan 2018 di Provinsi Jawa Timur, serta keterkaitan antara keterpilihan perempuan dalam Pilkada dengan menggunakan pendekatan dengan basis keterpilihan, pola rekrutmen, ikatan dengan masyarakat grassroot serta strategi kampanye dengan konsep Gender and Development. Penggunaan pendekatan dengan lima basis analisis tersebut dengan dikaitkan dengan konsep Gender and Development memiliki korelasi satu sama lain. Keterlibatan perempuan dalam politik merupakan salah satu bentuk capaian Gender and Development namun capaian tersebut dapat dilihat dengan basis-basis analisis seperti basis keterpilihan, pola rekrutmen, kaderisasi, kedekatan dengan grassroot serta strategi kampanye yang mempengaruhi keterpilhan perempuan dalam Pilkada.

\section{Perspektif Teori \\ 2.1 Konsep WID dan GAD}

Konsep pembangunan baik pembangunan fisik maupun non fisik hendaknya memperhatikan berbagai aspek di dalamnya, termasuk aspek perempuan. Namun, faktanya dalam berbagai kasus di lapangan, dalam proses pembangunan perempuan kerapkali dikondisikan sebagai pihak yang berada di "belakang", bukan sebagai pengambil keputusan, akibatnya banyak kebijakan pembangunan yang tidak ramah perempuan. Problemproblem tersebut menjadi alasan betapa pentingnya pelibatan perempuan dalam proses pembangunan. Selain itu, dengan pelibatan perempuan dalam pembangunan, setidaknya terdapat upaya-upaya untuk menghindari dominasi salah satu jenis kelamin, dalam hal ini laki-laki, serta menciptakan ruang partisipasi bagi perempuan sehingga mereka tidak lagi dijadikan objek dalam pembangunan.

Melalui latar belakang tersebut, maka muncul konsep mengenai Women 
in Development (WID) pada awal tahun 1970an. Pada saat itu, perempuan hanya dipandang sebagai penerima hasil atau objek dari pembangunan bukan aktor pembangunan. Hal tersebut tentu tidak terlepas pada adanya argumen yang menyebut bahwa hanya laki-laki yang dapat masuk ke dalam ranah produksi (publik), sedangkan perempuan bekerja pada ruang reproduksi (sektor domestik). Salah satu peletak dasar konsep WID ialah Ester Boserup dalam penelitiannya yang berjudul Women's Role in Economic Development (1970), Boserup menuntut berdasarkan hasil penelitiannya mengenai perempuan di kawasan pertanian Afrika, agar perempuan dilibatkan dalam pembangunan, tidak hanya di sektor domestik tetapi juga di sektor publik. (Razzavi dan Miller, 1995 :5-6).

Konsep Women in Development (WID) lebih menekankan kepada pelibatan perempuan pada proses pembangunan, dalam hal ini ruang produksi. Perempuan dan laki-laki dianggap memiliki kualitas dan kapabilitas yang sama dalam sektor produksi, baik pertanian maupun industri. (Razzavi dan Miller, 1995: 5). Namun, pendekatan tersebut masih memiliki berbagai kelemahan. Konsep WID dianggap hanya memperjuangkan keterlibatan perempuan pada aspek ekonomi saja, namun tidak memperjuangkan persamaan perempuan dan laki-laki pada aspek lain, misalnya pada aspek pemerintahan, pendidikan dan lain-lain. Salah satu impact dari adanya gerakan WID ini ialah justru adanya marjinalisasi terhadap perempuan itu sendiri akibat modernisasi yang berujung pada penyingkiran perempuan pada pekerjaan produktif.

Setelah konsep WID dianggap memiliki berbagai kelemahan, kemudian muncul konsep Gender and Development (GAD). Konsep GAD bertujuan untuk membongkar budaya patriarki, sekat yang memisahkan antara laki-laki dan perempuan dari berbagai aspek seperti aspek sosial, ekonomi, politik, pendidikan hingga lingkungan. Dalam hal ini, tidak ada lagi pembatasan ranah laki-laki maupun ranah perempuan, keduanya memiliki kesempatan yang sama dalam berbagai aspek kehidupan sesuai dengan kapasitas dan kemampuan masing-masing. Dalam hal ini, kesetaraan harus diprioritaskan. (Razzavi dan Miller, 1995 : 6).

Jika pada konsep WID lebih menekankan keterlibatan perempuan dalam aspek produksi, konsep GAD menekankan pada kesetaraan di antara kedua jenis kelamin tersebut, tidak ada prioritas khusus karena keduanya memiliki kualitas yang sama. Gender and Development menekankan pada konsep "gender" yang diartikan secara sederhana berarti sebuah konstruksi sosial yang dibentuk oleh masyarakat, sehingga dalam konsep GAD ini tidak ada dominasi dalam proses pembangunan. $\mathrm{Hal}$ yang sangat dibutuhkan untuk mempercepat tercapainya GAD ialah restrukturisasi pemikiran masyarakat yang masih cenderung berpikiran patriarki.

Adanya konsep Gender and Development (GAD) dianggap mampu membuka gap antara laki-laki dan perempuan yang selama berabad-abad terkungkum dalam budaya patriarki. GAD membuka kesempatan bagi perempuan untuk berkembang dan berproses sebagaimana kemampuan dan minatnya. Konsep GAD juga berhasil meluruskan pandangan dikotomi bahwa laki-laki memiliki kemampuan superior dan perempuan adalah mahluk inferior. 
Sehingga dengan adanya konsep GAD ini, banyak kita temui di berbagai bidang sosok perempuan menjadi pemimpin.

\subsection{Teori Demokrasi}

Seymour Martin Lipset (1959) sejak lama mengungkapkan tentang perlunya melihat prasyarat sosial bagi perkembangan demokrasi. Menurutnya, pembangunan ekonomi yang efektif berkorelasi positif dengan demokrasi. (Lipset, 1959: 69-105). Hal senada juga dinyatakan oleh Guillermo A. O' Donnel (2004), bahwa salah satu komponen penting bahkan sangat dasar dari demokrasi, yang selama ini kerap diabaikan, adalah manusia dalam hal ini warga negara. O'Donnel percaya ada hubungan erat antara demokrasi, pembangunan manusia (Human Development), dan hak asasi manusia (Human Rights). (O Donnel, 2004: 9-10). Wujud dari representasi hubungan erat antara demokrasi, pembangunan manusia dan hak asasi manusia salah satunya diwujudkan dalam konteks pemberian kesempatan yang sama bagi warga negara dalam berbagai hal, termasuk dalam bidang politik bagi perempuan. Pemberian kesempatan politik bagi perempuan salah satunya dengan memberikan akses yang seluas-luasnya bagi perempuan untuk masuk ke ranah politik, salah satunya yakni dengan mendukung pencalonan perempuan dalam Pilkada atau Pemilu. Sebagai negara yang menganut sistem demokratis, Indonesia telah cukup sukses dalam hal memberikan kesempatan/ akses kepada perempuan untuk terjun ke ranah politik. Salah satu contohnya ialah banyaknya calon kepala daerah perempuan yang terpilih dalam Pilkada, maupun keterpilihan perempuan dalam Pemilu legislatif. Namun, keterpilihan tersebut dapat dianalisis dengan beberapa faktor atau pendekatan keterpilihan perempuan dalam pemilu. Antara lain, basis keterpilihan yang melihat dari latar belakang apakah calon tersebut berasal, pola rekrutmen yang melihat bagaimana rekrutmen calon tersebut apakah berasal dari partai politik atau calon independen, serta bagaimana mekanisme rekrutmennya. Pendekatan selanjutnya yakni kaderisasi yang melihat bagaimana kandidat tersebut dikader, apakah kader internal partai politik atau bukan, selanjutnya yakni kedekatan dengan grassroot yang melihat apakah kandidat tersebut memiliki kedekatan dengan grassroot, yang kemudian berkorelasi dengan strategi kampanye yang dilakukan oleh kandidat.

\section{Hasil dan Pembahasan}

Pemilihan kepala daerah di Indonesia telah ada sejak era Orde Lama yang diatur melalui Undangundang Nomor 1 Tahun 1957 Tentang Pemerintahan Daerah. Undang-Undang tersebut mengamanatkan kepada seluruh anggota Dewan Perwakilan Rakyat Daerah (DPRD) untuk memilih sendiri pimpinannya di daerah, baik itu gubernur maupun walikota/bupati. Pada era Orde Baru, pengaturan mengenai pemilihan kepala daerah diatur dalam Undangundang Nomor 5 Tahun 1974 Tentang Pemerintahan Daerah yang menyebutkan bahwa kepala daerah dipilih oleh DPRD, namun pengesahan dan pelantikan para calon yang terpilih diserahkan pada Kementerian Dalam Negeri (Kemendagri). 
Pasca jatuhnya rezim Orde Baru, Pemerintah Indonesia dibawah pimpinan Presiden BJ Habibie mengeluarkan Undang-Undang Nomor 22 Tahun 1999 Tentang Pemerintahan Daerah. Dalam Undang-undang tersebut pemilihan kepala daerah dilakukan sepenuhnya oleh DPRD dan kepala daerah bertanggung jawab juga kepada DPRD. Pemilihan Kepala Daerah dan Wakil Kepala Daerah dilaksanakan secara langsung, bebas, rahasia, jujur dan adil. Adapun mekanisme pemilihannya adalah setiap anggota DPRD memiliki satu suara untuk memilih calon kepala daerah, siapapun pasangan calon yang memenangkan pemilihan di tingkat DPRD secara otomatis menjadi kepala daerah dan wakil kepala daerah. Pemerintah pusat hanya berwenang untuk mengesahkan hasil yang telah disepakati di daerah. Setelah terpilih, kepala daerah terpilih dilantik oleh presiden atau pejabat yang ditunjuk presiden.

Undang-Undang Nomor 22 Tahun 1999 tersebut kemudian direvisi karena dianggap terlalu liberal untuk konteks Negara Kesatuan Republik Indonesia (NKRI). Revisi tersebut menjadi Undang-Undang Nomor 32 Tahun 2004 Tentang Pemerintah Daerah. Pemilihan kepala daerah diimpementasikan pada pertengahan tahun 2005 dengan berlandaskan Undang -Undang Nomor 32 Tahun 2004 dan Peraturan Pemerintah Nomor 6 Tahun 2005 Tentang Pemilihan, Pengesahan Pengangkatan, dan Pemberhentian Kepala Daerah dan Wakil Kepala Daerah. Dalam undangundang tersebut dijelaskan pula bahwa kepala daerah dan wakil kepala daerah dipilih dalam satu pasangan calon yang dilaksanakan secara demokratis berdasarkan asas langsung, umum, bebas, rahasia, jujur dan adil. Secara lebih jelas dalam Undang-undang tersebut dijelaskan bahwa kepala daerah dan wakil kepala daerah dipilih dalam satu pasangan secara langsung oleh rakyat di daerah yang bersangkutan. Undang-undang tersebutlah yang kemudian mengilhami dilaksanakannya Pilkada secara langsung, dimana rakyat di daerah memiliki otoritas tersendiri dalam menentukan pemimpin di daerahnya.

Namun, pelaksanaan Pilkada secara langsung ini kemudian menuai berbagai aksi pro dan kontra baik di kalangan elit politik maupun di kalangan masyarakat umum. Terdapat berbagai stigma negatif terkait pelaksanaan Pilkada secara lansung. Pilkada langsung kerap dianggap sebagai sebuah pemborosan anggaran negara, serta penyumbang kasus korupsi dimana banyak kepala daerah terpilih terlibat kasus korupsi. Hal tersebut disinyalir akibat tingginya ongkos Pilkada. Hingga akhirnya DPR menerbitkan Undang-Undang Nomor 23 Tahun 2014 Tentang Pemerintahan Daerah. Undangundang tersebut menyatakan bahwa kepala daerah tidak lagi dipilih secara langsung melainkan dipilih oleh DPRD. Namun, penghapusan mekanisme pilkada langsung dengan mengembalikan pilkada dilakukan oleh DPRD ini kemudian menuai berbagai polemik di masyarakat.

Hingga Presiden Susilo Bambang Yudhoyono diakhir masa jabatannya menerbitkan Perppu Nomor 1 Tahun 2014 yang secara langsung menghapus kewenangan DPRD untuk memilih kepala daerah. Selain itu, presiden juga menerbitkan Perppu Nomor 2 Tahun 2014 Tentang Pemerintahan Daerah, yang kemudian di tetapkan menjadi 
Undang Undang Nomor 1 Tahun 2015 dan Undang-Undang Nomor 8 Tahun 2015 Tentang Pemilihan Kepala Daerah. Sejak diterbitkannya undang-undang tersebut pemilihan kepala daerah tetap dilaksanakan secara langsung dengan dipilih oleh rakyat. Namun, demi efisiensi anggaran negara pelaksanaan Pilkada langsung dilakukan secara serentak dalam beberapa gelombang. Pelaksanaan Pilkada serentak gelombang pertama dilaksanakan pada Desember 2015, Pilkada serentak gelombang kedua pada Februari 2017 serta Pilkada serentak gelombang ketiga dilaksanakan pada Juni 2018.(Kompas.com, 19 Juni 2018). Selain merupakan wujud representasi dari kedaulatan rakyat, Pilkada langsung juga merupakan salah satu sarana akomodasi bagi partisipasi politik perempuan di aras lokal. Hal tersebut dapat dibuktikan dengan semakin meningkatnya jumlah kepala daerah perempuan di Indonesia, salah satunya di Provinsi Jawa Timur yang hingga saat ini memiliki sepuluh kepala daerah.

\section{- Keterpilihan Perempuan dalam Pilkada Serentak di Jawa Timur Tahun 2015}

Pilkada serentak tahun 2015 merupakan rangkaian Pilkada serentak gelombang pertama di Indonesia, yang diikuti oleh 269 daerah, namun pada praktiknya hanya diikuti 264 daerah karena lima daerah lainnya mengalami penundaan pelaksanaan Pilkada. Kelima daerah tersebut yakni Provinsi Kalimantan Tengah, Kabupaten Fakfak, Kota Pematangsiantar, Kabupaten Simalungun, dan Kota Manado. (www. kompas.com, diakses pada 19 Agustus 2018). Dalam pelaksanaan Pilkada serentak gelombang pertama tersebut, terdapat 19 pilkada di Kabupaten Kota se-Jawa Timur.(www.sindonews.com, 19 September 2018). Adapun Kabupaten/ Kota yang menyelenggarakan Pilkada serentak antara lain Kota Surabaya, Kabupaten Sidoarjo, Kabupaten Malang, Kabupaten Kediri, Kabupaten Gresik, Kabupaten Lamongan, Kabupaten Tuban, Kota Pasuruan, Kabupaten Situbondo, Kabupaten Banyuwangi, Kabupaten Jember, Kabupaten Sumenep, Kabupaten Trenggalek, Kabupaten Blitar, Kota Blitar, Kabupaten Pacitan, Kabupaten Ponorogo dan Kabupaten Ngawi.(Sindonews.com, 14 September 2018). Pilkada tersebut diikuti oleh 92 pasangan calon, yang terdiri atas 12 calon kepala daerah perempuan, dan 80 laki-laki. Dari hasil Pilkada tersebut, terdapat tiga kepala daerah perempuan yang terpilih yakni Tri Rismaharini terpilih sebagai Walikota Surabaya dengan perolehan suara sebesar $86,34 \%$ suara, Faida terpilih sebagai Bupati Jember dengan perolehan suara 53,76\% suara, serta Haryanti terpilih sebagai Bupati Kediri dengan perolehan suara sebesar 54,58\%. (beritagar, 14 September 2018).

Tabel 1. Kepala daerah Perempuan terpilih dalam Pilkada Serentak tahun 2015 Provinsi Jawa Timur

\begin{tabular}{|c|l|l|l|}
\hline No & \multicolumn{1}{|c|}{ Nama } & Pengusung & $\begin{array}{c}\text { Latar } \\
\text { Belakang }\end{array}$ \\
\hline 1 & Tri & PDI P & Walikota \\
& Rismaharini & & $\begin{array}{l}\text { Incumbent, } \\
\text { sebelum } \\
\end{array}$ \\
& & & menjadi \\
& & & walikota \\
& & & merupakan \\
& & & birokrat. \\
\hline
\end{tabular}




\begin{tabular}{|c|c|c|c|}
\hline 2 & Faida & $\begin{array}{l}\text { PAN, Partai } \\
\text { Demokrat }\end{array}$ & $\begin{array}{l}\text { Dokter, } \\
\text { anak } \\
\text { pemilik RS } \\
\text { Al Huda }\end{array}$ \\
\hline 3. & $\begin{array}{l}\text { Haryanti } \\
\text { Sutrisno }\end{array}$ & $\begin{array}{l}\text { PDI P, PKB, } \\
\text { Partai } \\
\text { Demokrat, } \\
\text { dan PBB. }\end{array}$ & $\begin{array}{l}\text { Incumbent, } \\
\text { Istri } \\
\text { Pertama } \\
\text { Bupati } \\
\text { Kediri } \\
\text { periode } \\
2005- \\
2010, \text { pada } \\
\text { Pilkada } \\
2010 \\
\text { melawan } \\
\text { istri kedua } \\
\text { Bupati } \\
\text { Kediri } \\
\text { Sutrisno. }\end{array}$ \\
\hline
\end{tabular}

Data diolah dari berbagai sumber

\section{- Keterpilihan Perempuan dalam Pilkada Serentak di Jawa Timur tahun 2017}

Pada tahun 2017, Indonesia kembali melaksanakan Pilkada serentak di 101 daerah di Indonesia. Kota Batu merupakan satu-satunya daerah di Jawa Timur yang melaksanakan Pilkada pada tahun 2017. Pilkada Kota Batu diikuti oleh empat pasangan calon, yakni pasangan Rudi Sujono-Djonet yang diusung oleh PAN, Partai Hanura, Partai Nasdem. Pasangan calon berikutnya yakni Dewanti RumpokoPanjul Santoso yang diusung oleh PDI Perjuangan, Partai Golkar, Partai Gerindra dan PKS. Pasangan ketiga yakni pasangan Hairuddin Hendra-Angga Sonatha yang diusung oleh PKB dan Partai Demokrat, serta Abdul Majid-Kasmuri Idris yang maju dari jalur perseorangan(incumbent). Pilkada Kota Batu dimenangkan oleh pasangan calon Dewanti RumpokoPunjul Santoso dengan perolehan suara sebesar 51.748 suara atau sekitar $44,46 \%$ suara. Keterpilihan Dewanti Rumpoko sebagai walikota Kota Batu menambah daftar keterwakilan perempuan dalam ranah eksekutif lokal. Dewanti Rumpoko merupakan istri dari Eddy Rumpoko yang merupakan walikota Kota Batu selama dua periode, 2007-2017. Sebelumnya, Dewanti Rumpoko pernah dua kali gagal dalam Pilkada, yakni pada Pilkada Bupati Malang tahun 2015 serta Pilkada Kota Malang tahun 1999 yang kala itu pemilihan kepala daerah masih dipilih oleh DPRD. (m.detik.com, 14 September 2018).

\section{- Keterpilihan Perempuan dalam Pilkada Serentak Provinsi Jawa Timur tahun 2018}

Pilkada tahun 2018 merupakan rangkaian pilkada serentak gelombang ketiga yang diikuti oleh 171 daerah di Indonesia. Dalam Pilkada tersebut, terdapat 101 calon kepala daerah perempuan yang bertarung untuk memperebutkan posisi kepala daerah. Provinsi Jawa Timur merupakan salah satu daerah yang melaksanakan Pilkada serentak tahun 2018, dengan pemilihan gubernur dan wakil gubernur serta pemilihan bupati/ walikota di 18 daerah di Jawa Timur. Adapun daerah yang menggelar Pilkada serentak tahun 2018 di Jawa Timur antara lain Kabupaten Lumajang, Kabupaten Bondowoso, Kabupaten Probolinggo, Kabupaten Pasurusan, Kota Malang, Kabupaten Nganjuk, Kabupaten Jombang, Kota Kediri, Kota Madiun, Kabupaten Madiun, Kabupaten Magetan, Kabupaten Tulungagung, Kota Mojokerto, Kabupaten Bojonegoro, Kabupaten Bangkalan, Kabupaten Sampang dan Kabupaten Pamekasan. (m.detik.com, 14 September 2018). 
Hasil Pilkada serentak tahun 2018 di Provinsi Jawa Timur terdapat tujuh calon kepala daerah yang terpilih dalam kontestasi Pilkada. Ketujuh calon pilkada tersebut meliputi satu orang gubernur, tiga orang bupati, satu orang walikota, satu orang calon wakil walikota serta satu orang calon wakil bupati, yakni Khofifah Indar Parawansa terpilih sebagai Gubernur Jawa Timur, Puput Tantriana Sari terpilih sebagai Bupati Probolinggo, Lilik Muhibah terpilih sebagai Wakil Walikota Kediri, Ana Muawanah terpilih sebagai Bupati Bojonegoro, Mundjidah Wahab terpilih sebagai Bupati Jombang, Ika Puspitasari terpilih sebagai Walikota Mojokerto, Indah Amperawati terpilih sebagai Wakil Bupati Lumajang.

\section{- Analisis}

Keterlibatan dan keterpilihan perempuan dalam pilkada serentak merupakan salah satu bentuk dari capaian gender and development. Sebagaimana dijelaskan sebelumnya, gender and development adalah konsep yang menekankan pada kesetaraan di antara kedua jenis kelamin yakni lakilaki dan perempuan, tidak ada prioritas khusus karena keduanya memiliki kualitas yang sama. Gender and Development menekankan pada konsep "gender" yang diartikan secara sederhana berarti sebuah konstruksi sosial yang dibentuk oleh masyarakat, sehingga dalam konsep GAD ini tidak ada dominasi dalam proses pembangunan dalam hal ini adalah politik. Para perempuan peserta Pilkada dalam pencalonannya, dihadapkan dengan beberapa calon laki-laki, tidak ada regulasi atau perlakuan khusus bagi kandidat perempuan maupun laki-laki dalam Pilkada. Oleh karenanya, Pilkada langsung sering disebut sebagai arena pertarungan bebas bagi para kandidat tanpa melihat jenis kelamin. Namun, upaya perempuan dalam memasuki ranah politik tidaklah mudah. Lovenduski (2008) dalam bukunya yang berjudul "Politik Berparas Perempuan" menyatakan pentingnya keterlibatan perempuan dalam politik. Namun, Lovenduski mengakui bahwa perempuan menghadapi rintangan yang serius untuk menjadi pelaku politik.

Adapun rintangan yang dihadapi perempuan untuk masuk ke ranah politik antara lain, pertama, sumber daya perempuan yang diperlukan untuk memasuki wilayah politik lebih lemah. Secara umum, perempuan lebih miskin dari pada laki-laki dan cenderung tidak ditempatkan pada jabatan-jabatan yang mendukung kegiatan politik. Kedua, bermacam-macam kekangan gaya hidup yang menyebabkan perempuan mempunyai sedikit waktu untuk politik. Keluarga dan kewajiban-kewajiban lain yang menuntut kewajiban penuh secara khusus dijalankan oleh perempuan telah mengurangi waktu mereka untuk melakukan kegiatan lain. Terkadang, dalam keadaan tertentu perempuan kerapkali dihadapkan dengan konflik peran dan status yang mereka miliki. Rintangan ketiga yakni politik selalu diidentikkan dengan wajah maskulin. Tugas politik dikategorikan sebagai tugas laki-laki yang menghalangi kaum perempuan mengejar karier politik dan menghalangi rekruetmen politik bagi mereka yang ingin tampil ke publik. (Lovenduki, 2008, 88).

Berikut daftar kepala daerah perempuan di Provinsi Jawa Timur: 
Tabel 2. Daftar Kepala Daerah

Perempuan di Provinsi Jawa Timur

\begin{tabular}{|c|c|c|c|c|}
\hline No & Nama & Jabatan & Pengusung & $\begin{array}{l}\text { Latar } \\
\text { Belakang }\end{array}$ \\
\hline 1. & $\begin{array}{l}\text { Khofifah } \\
\text { Indar } \\
\text { Parawansa }\end{array}$ & $\begin{array}{l}\text { Gubernur } \\
\text { Jawa } \\
\text { Timur }\end{array}$ & $\begin{array}{l}\text { Partai } \\
\text { Demokrat, } \\
\text { PAN, Partai } \\
\text { Nasdem, } \\
\text { Partai } \\
\text { Hanura, } \\
\text { PPP }\end{array}$ & $\begin{array}{l}\text { Aktivis } \\
\text { Muslimat } \\
\text { NU, Menteri } \\
\text { Peranan } \\
\text { Wanita, } \\
\text { Menteri Sosial, } \\
\text { tiga kali maju } \\
\text { sebagai calon } \\
\text { gubernur Jawa } \\
\text { Timur (2008, } \\
\text { 2013 dan } \\
\text { 2018). }\end{array}$ \\
\hline 2. & $\begin{array}{l}\text { Tri } \\
\text { Rismaharini }\end{array}$ & $\begin{array}{l}\text { Walikota } \\
\text { Surabaya }\end{array}$ & PDI P & $\begin{array}{l}\text { Incumbent } \\
\text { (Walikota } \\
\text { Surabaya } \\
\text { 2010-2015), } \\
\text { Birokrat, } \\
\text { beberapa kali } \\
\text { menerima } \\
\text { penghargaan } \\
\text { sebagai } \\
\text { Walikota } \\
\text { terbaik. }\end{array}$ \\
\hline 3. & $\begin{array}{l}\text { Puput } \\
\text { Tantriana } \\
\text { Sari }\end{array}$ & $\begin{array}{l}\text { Bupati } \\
\text { Proboling- } \\
\text { go }\end{array}$ & $\begin{array}{l}\text { PDI P, PPP, } \\
\text { Partai } \\
\text { Nasdem, } \\
\text { Partai } \\
\text { Golkar dan } \\
\text { Gerindra }\end{array}$ & $\begin{array}{l}\text { Incumbent, } \\
\text { Istri Bupati } \\
\text { Probolinggo, } \\
\text { Hasan } \\
\text { Aminuddin } \\
\text { periode 2003- } \\
2013 \text {. }\end{array}$ \\
\hline 4. & Faida & $\begin{array}{l}\text { Bupati } \\
\text { Jember }\end{array}$ & $\begin{array}{l}\text { Partai } \\
\text { Demokrat, } \\
\text { PAN }\end{array}$ & Dokter \\
\hline 5. & $\begin{array}{l}\text { Haryanti } \\
\text { Sutrisno }\end{array}$ & $\begin{array}{l}\text { Bupati } \\
\text { Kediri }\end{array}$ & $\begin{array}{l}\text { PDI P, PKB, } \\
\text { Partai } \\
\text { Demokrat, } \\
\text { dan PBB }\end{array}$ & $\begin{array}{l}\text { Incumbent, } \\
\text { Bupati Kediri } \\
\text { periode } \\
\text { 2010-2015, } \\
\text { istri pertama } \\
\text { mantan Bupati } \\
\text { Kediri Sutrisno }\end{array}$ \\
\hline 6. & $\begin{array}{l}\text { Dewanti } \\
\text { Rumpoko }\end{array}$ & $\begin{array}{l}\text { Walikota } \\
\text { Batu }\end{array}$ & $\begin{array}{l}\text { PDI P, Partai } \\
\text { Golkar, } \\
\text { Partai } \\
\text { Gerindra } \\
\text { dan PKS }\end{array}$ & $\begin{array}{l}\text { Istri Walikota } \\
\text { Batu Eddy } \\
\text { Rumpoko, tiga } \\
\text { kali mengikuti } \\
\text { kontestasi } \\
\text { Pilkada, Dosen. }\end{array}$ \\
\hline 7. & $\begin{array}{l}\text { Rukmini } \\
\text { Buchori }\end{array}$ & $\begin{array}{l}\text { Walikota } \\
\text { Proboling- } \\
\text { go (2014- } \\
2019)\end{array}$ & PDI P & $\begin{array}{l}\text { Istri Walikota } \\
\text { Probolinggo } \\
\text { M Buchori, } \\
\text { sebelum } \\
\text { menjadi } \\
\text { walikota } \\
\text { Rukmini } \\
\text { merupakan } \\
\text { anggota DPR RI } \\
\text { dari PDI P. Pada } \\
\text { Pilkada 2018, } \\
\text { Rukmini tidak } \\
\text { mendapatkan } \\
\text { dukungan } \\
\text { partai. }\end{array}$ \\
\hline
\end{tabular}

\begin{tabular}{|c|l|l|l|l|}
\hline 8. & $\begin{array}{l}\text { Mundjidah } \\
\text { Wahab }\end{array}$ & $\begin{array}{l}\text { Bupati } \\
\text { Jombang }\end{array}$ & $\begin{array}{l}\text { PPP, Partai } \\
\text { Geridra, } \\
\text { Partai } \\
\text { Demokrat }\end{array}$ & $\begin{array}{l}\text { Wakil Bupati } \\
\text { Jombang 2013- } \\
\text { 2018, anggota } \\
\text { DPRD sejak } \\
\text { tahun 1971 } \\
\text { hingga tahun } \\
\text { 2012. }\end{array}$ \\
\hline 9. & $\begin{array}{l}\text { Ita } \\
\text { Puspitasari }\end{array}$ & $\begin{array}{l}\text { Wojokerto } \\
\text { Molikota }\end{array}$ & $\begin{array}{l}\text { Partai } \\
\text { Golkar dan } \\
\text { Gerindra }\end{array}$ & $\begin{array}{l}\text { Adik Bupati } \\
\text { Mojokerto, } \\
\text { Mustafa Kemal } \\
\text { Pasa }\end{array}$ \\
\hline 10. & $\begin{array}{l}\text { Anna } \\
\text { Muawan- } \\
\text { nah }\end{array}$ & $\begin{array}{l}\text { Bupati } \\
\text { Bojone- } \\
\text { goro }\end{array}$ & $\begin{array}{l}\text { PKB, PDI P, } \\
\text { PKPI }\end{array}$ & $\begin{array}{l}\text { Anggota DPR } \\
\text { RI fraksi PKB } \\
\text { selama tiga } \\
\text { periode }\end{array}$ \\
\hline
\end{tabular}

Data diolah dari berbagai sumber

Keterpilihan perempuan dalam Pilkada tidak dapat hanya dianalisis melalui jumlah perempuan yang menjadi kepala daerah saja. Paper ini setidaknya menganalisis keterpilihan perempuan dalam Pilkada serentak di Jawa Timur dengan menggunakan beberapa indikator, yakni Basis keterpilihan, Pola rekruitmen, kaderisasi, ikatan dengan masyarakat grassroot serta strategi kampanye.

Basis keterpilihan adalah darimana calon tersebut dipilih, apakah dari golongan elite, selebritis, politik dinasti, atau aktivis. Dari data di atas, diketahui bahwa beberapa kepala daerah perempuan di Jawa Timur memiliki latar belakang hubungan kekerabatan dengan elite politik. Sebagian dari mereka adalah istri dari mantan kepala daerah yang masa jabatannya telah habis atau kandidat yang memiliki hubungan keluarga dengan kepala daerah lainnya. Namun, beberapa dari para kepala daerah perempuan terpilih Jawa Timur juga merupakan aktivis, seperti Khofifah Indar Parawansa selain merupakan politisi senior dengan berbagai pengalamannya, Kofifah juga merupakan aktivis Muslimat NU, yang merupakan salah satu organisasi perempuan dengan basis massa terbesar di Indonesia. Selain itu, jika dianalisis dari basis keterpilihan 
beberapa kepala daerah perempuan di Jawa Timur juga memiliki latar belakang sebagai profesional seperti dokter, birokrat dan dosen. Jadi, secara basis keterpilihan, para kepala daerah terpilih di Provinsi Jawa Timur berasal dari berbagai basis antara lain elite politik baik itu merupakan pengurus partai politik, anggota legislatif atau seseorang yang memiliki kedekatan dengan elite politik (politik dinasti), aktivis, serta kalangan profesional seperti dokter, dosen dan birokrat.

Indikator berikutnya yakni pola rekrutmen, darimana calon tersebut direkrut, apakah dari jalur perseorangan atau jalur partai politik. Barbara Geddes membedakan empat model rekrutmen, yakni partisanship, yaitu partai politik yang mempertimbangkan loyalitas seseorang kepada partai politik. Selanjutnya, meritocratic, yaitu rekruitmen politik dari kalangan yang memiliki potensi tinggi. Model rekrutmen yang ketiga yakni compartementalization, yaitu rekrutmen politik yang dilakukan berdasarkan pertimbangan pragmatis, dan model yang keempat adalah survival, yaitu rekrutmen politik berdasarkan prinsip balas jasa dan sumber daya pelamar dan cenderung bersifat patronase.(Geddes, 1996: 142181) Berdasarkan pola rekrutmennya, sepuluh kepala daerah perempuan terpilih di Provinsi Jawa Timur merupakan kepala daerah yang diusung oleh partai politik. Sedangkan terkait model rekrutmennya, jika dilihat dari latar belakang kandidat, model rekrutmennya pun berbeda-beda. Seperti misalnya Mundjidah Wahab yang telah bergabung dengan PPP sejak awal pembentukannya dan dalam Pilkada 2018 ia kembali diusung oleh PPP tentu model rekrutmennya adalah partisanship. Hal tersebut dapat dilihat dari latar belakang politik Mundjidah yang sejak tahun 1971 hingga tahun 2012 telah menjadi anggota DPRD baik tingkat Kabupaten maupun Provinsi yang diusung oleh Partai Persatuan Pembangunan (PPP).

Secara kaderisasi, beberapa kepala daerah perempuan terpilih di Jawa Timur merupakan kandidat partai politik yang telah lama berproses di Partai Politik. Misalnya, Mundjidah Wahab yang telah menjadi anggota DPRD sejak tahun 1971 hingga tahun 2012, serta memiliki jabatan struktural di internal PPP dari mulai tingkat ranting hingga provinsi. Contoh lain misalnya, Anna Muawanah yang merupakan politisi PKB dan pernah menjabat sebagai anggota DPR RI selama tiga periode. Dewanti Rumpoko, meskipun ia memiliki latar belakang sebagai istri dari mantan Walikota Batu, namun karier politiknya juga tidak dapat diragukan. Dewanti telah mengikuti kaderisasi politik sejak era reformasi, hal tersebut dibuktikan dengan pencalonannya sebagai calon Walikota Malang pada tahun 1999, meskipun ia tidak terpilih, namun pencalonan perempuan pada era tersebut merupakan suatu hal yang langka dan patut diapresiasi. Sebagaimana diketahui, pada awal reformasi, pemilihan kepala daerah masih dilakukan oleh DPRD. Pada era tersebut keterpilihan perempuan dalam Pilkada masih sangat rendah. Tercatat hanya ada empat perempuan yang terpilih sebagai kepala daerah saat itu yakni Rustriningsih sebagai Bupati Kebumen (2000-2005), Haeny Relawati Bupati Tuban (2001-2006), Rina Iriani Bupati Karang Anyar (2003-2008) dan Tuti Hayati Anwar Bupati Majalengka (20032008). (Kurniawati, $2016: 1$ ).

Sedangkan secara ikatan dengan grassroot beberapa kepala daerah 
perempuan terpilih di Jawa Timur memiliki kedekatan dengan masyarakat akar rumput. Kedekatan dengan masyarakat akar rumput tersebut kemudian juga berkaitan dengan strategi kampanye yang dilakukan oleh para kandidat kepala daerah. Salah satu contoh kepala daerah perempuan terpilih di Provinsi Jawa Timur yang memiliki kedekatan dengan masyarakat akar rumput ialah Khofifah Indar Parawansa. Hal tersebut selain dikarenakan latar belakang Khofifah yang merupakan aktivis Muslimat, sosok Khofifah yang dekat dengan kalangan santri, pesantren, juga menjadi bukti kedekatan Khofifah dengan masyarakat akar rumput. Dalam strategi kampanyenya, Khofifah dapat mendatangi 19 titik wilayah per hari. Contoh lain kepala daerah perempuan Jawa Timur yang memiliki kedekatan dengan akar rumput ialah Tri Risma Harini. Sosok Risma tidak hanya populer dikalangan warga Surabaya saja, tetapi juga hampir di seluruh Indonesia, sehingga tidak mengherankan jika dalam kontestasi Pilkada tahun 2015 di Kota Surabaya Risma mampu meraih suara $86,34 \%$ suara atau sekitar 893.087 suara.(www.m.antaranews.com, 28 Oktober 2018).

Berdasarkan empat indikator tersebut, dapat disimpulkan bahwa keterpilihan para kepala daerah perempuan di Jawa Timur pada Pilkada tahun 2015, 2017, 2018 dipengaruhi oleh berbagai hal antara lain faktor latar belakang kandidat yang terdiri dari elit, aktivis dan kalangan profesional, partai politik pengusung serta kedekatan dengan grassroot yang kemudian berkorelasi dengan strategi kampanye yang dilakukan oleh para kandidat.

\section{Simpulan}

Dari uraian dan berdasarkan data-data yang telah disebutkan sebelumnya, maka dapat disimpulkan bahwa keterpilihan perempuan dalam Pilkada merupakan salah satu bentuk capaian gender and development. Sebagaimana dijelaskan sebelumnya, gender and development adalah konsep yang menekankan pada kesetaraan diantara kedua jenis kelamin yakni laki-laki dan perempuan, tidak ada prioritas khusus karena keduanya memiliki kualitas yang sama, maka begitu pula yang terjadi dalam proses Pilkada. Dalam Pilkada di Jawa Timur misalnya, daerah yang dikenal dengan basis santri dan dengan budaya patriarki yang sangat melekat namun mampu memberikan ruang dan kesempatan yang sama bagi perempuan dalam Pilkada.

Sedangkan mengenai keterpilihan perempuan dalam Pilkada di Provinsi Jawa Timur tidak dapat dijelaskan dengan faktor tunggal. Hal tersebut dapat dianalisis dengan berbagai indikator antara lain basis keterpilihan yang merupakan latar belakang dari kandidat tesebut, apakah dari kalangan elit, akademisi, pengusaha dan lain-lain. Berdasarkan hasil penelitian, basis keterpilihan perempuan dalam Pilkada di Jawa Timur didominasi oleh kalangan elit politik yakni anggota legislatif, pejabat eksekutif/pemerintahan, serta hubungan kekerabatan dengan Bupati/Walikota sebelumnya, aktivis serta kalangan profesional. Selain itu, pola rekrutmen dan kaderisasi juga berpengaruh dalam keterpilihan, dalam hal ini sepuluh kepala daerah perempuan Provinsi Jawa Timur berdasarkan pola rekrutmennya merupakan kandidat yang diusung oleh Partai Politik. Sedangkan secara kaderisasi, 
terdapat beberapa calon yang mengikuti kaderisasi partai politik sejak awal tetapi ada juga yang tidak mengikuti kaderisasi sejak awal. Sedangkan secara kedekatan dengan masyarakat akar rumput, beberapa kepala daerah perempuan di Jawa Timur memiliki kedekatan dengan masyarakat akar rumput, hal tersebut dibuktikan dengan begitu dikenalnya beberapa kandidat calon kepala daerah perempuan tersebut di berbagai kalangan, misalnya seperti nama Walikota Surabaya Risma, yang memiliki kedekatan dengan masyarakat hingga namanya tidak hanya dikenal di kalangan masyarakat Surabaya, melainkan hampir oleh seluruh masyarakat Indonesia. hal tersebut kemudian berpengaruh dengan strategi kampanye, dan pada akhirnya akan mempengaruhi perilaku memilih masyarakat dalam Pilkada. 


\section{DAFTAR PUSTAKA}

\section{Buku:}

Barbara Geddes. (1996). Politicians Dilema: Building State Capacity in Latin America, University of California Press.

Huntington, Samuel. (2001). Gelombang Demokratisasi Ketiga, Jakarta: PT. Pustaka Utama Grafiti.

Joni Lovenduski. (2005). Politik Berparas Perempuan, Yogyakarta : Kanisius.

Lipset, Seymour Martin, "Some Social Requisites of Democracy: Economic Development and Political Legitimacy," The American Political Science Review, vol. 53, no. 1 (Mar, 1959)

O'Donnell, Guilermo,"Human Development, Human Rights, and Democracy," dalam Guillermo O'Donnell, Jorge Vargas Cullell, Osvaldo M. lazzetta (eds.), The Quality of Democracy Theory and Applications, (USA: University of Notre Dame Press, 2004).

Jurnal:

Kurniawati Hastuti Dewi, Konteks Sosial Ekonomi Kemunculan Perempuan Kepala Daerah, (Jurnal Penelitian Politik | Volume 13 No. 2 Desember 2016, LIPI) Nunung Komariah dkk, Perempuan di Pilkada Serentak 2015; Perspektif Perempuan dan Lingkar Kekuasaan di Sekitar Calon Perempuan Peserta Pilkada, Yogyakarta: Satunama, 2016.

Sharashoub Razavi dan Carol Miller, From WID to GAD: Conceptual Shifts in the Women and Development Discourse, Switzerland: UNRISD, Occasional Paper 1, February 1995

\section{Website:}

https://daerah.sindonews.com/read/1067929/23/19-kabupatenkota-di-jawa-timurgelar-pilkada-serentak-1449608197/13, 14 September 2018 pukul 12.15 WIB. beritagar.id, 14 September 2018 pukul 12.16 WIB.

https://m.detik.com pada 14 September 2018 pukul 09.21 WIB.

https://m.detik.com pada 14 September 2018 pukul 10.35 WIB.

www.jatim.tribunnews.com diakses pada 14 September 2018, pukul 10.23 WIB 
100 | Jurnal Adhyasta Pemilu 